\title{
Bereavement without a death
}

\author{
Rosamund Snow
}

When I was a kid I wanted to be the kind of person who can crash land in the desert and walk for days to safety; the loyal adventurer who won't give up searching the mountains for a friend even when everyone else is exhausted. Then I got a diagnosis of type 1 diabetes.

Life with type 1 is manageable, but it's hard work to be adventurous and it's impossible to be completely spontaneous. If I were dropped in the desert, I'd die pretty quickly. In fact, if I want to walk to the shops, or even eat a piece of fruit, I have to plan, think about what happened since my last injection and what is likely to happen before my next one; I have to carry emergency supplies; I have to do blood tests. I can't even have a drink without having to do maths.

Nobody real had died, but the person I wanted to be was gone forever.

\section{I hated the person I was supposed to become}

As a patient I had to be obedient or the doctors disapproved. Well meaning people wanted to pity me, while less well meaning people were disgusted by me as a burden on the health system. I felt trapped in a prison cell. People would look in and tell me how sorry they were for me, but they could always walk away, while I would never, ever escape.

I stopped sleeping and I started getting panic attacks, I made the kinds of detailed plans for suicide that should have rung every kind of alarm bell, but I kept looking for other reasons for my misery. I didn't connect it up with my "prison cell" nightmare or even the fact that when I went to have blood taken at the clinic, tears poured silently down my face all the way through. I went to a counsellor but didn't mention diabetes. It didn't cross my mind that it was acceptable to be grieving the fact that I was no longer healthy.

\section{“Good patients" can be deceptive}

Maybe the nurses noticed me crying and said something to my doctor, or maybe he was wise enough to know that just because my blood sugar was "well controlled" it didn't mean my emotions were. For the first time he asked me how I was feeling, rather than what my blood test strips said. I started to tell him that actually I'd had the diagnosis over a year, I was fine. But before I could say any of that, I started sobbing again.

He did two life saving things. Firstly, he told me that it was not surprising I was upset after a serious diagnosis like diabetes - that he would expect me to experience a bereavement process. Secondly, he told me to go and talk to Monica, one of the specialist nurses, who also had type 1 diabetes.

\section{An imperfect role model}

Why was Monica so valuable? Not because of her healthcare professional's expertise, but because she wasn't a perfect patient with diabetes. She knew how hard it is to be the weird one in a room of healthy people who really don't care or understand what we have to think about all the time. She still had days where she got angry and sad that she'd got this disease; she let me know it was okay to mourn who I used to be. I still thought I was stupid and selfish to be so upset, but something started to change in my head. I haven't followed the classic stages of grief, because like Monica I still have days when having diabetes makes me angry and sad and days where I'm just enormously tired of this never ending disease. But 25 years on, I'm no longer in denial and I've accepted who I am. It's even possible to move from grief to pride-those with type 1 diabetes are among the hardest working people you'll ever meet. I'm proud of us.

This article by BMJ Patient Editor Rosamund Snow was written a few months before she died (doi:10.1136/bmj.j850).

Published by the BMJ Publishing Group Limited. For permission to use (where not already granted under a licence) please go to http://group.bmj.com/group/rights-licensing/ permissions 


\section{What you need to know}

- A feeling of bereavement may occur after a change in health status, and it can take a long time to come to terms with it

- Patients may find it hard to accept that it's ok to grieve for lost health; telling them it's normal can make an enormous difference

- Sometimes the only person who can put things in perspective is someone going through the same experiences

\section{Education into practice}

- Have you considered that a patient or carer of a patient might grieve for a life or identity that is lost or altered by having to come to terms with living with a long term condition?

- How might you attempt to identify if someone is struggling in this respect?

- Does this article offer you any ideas on doing this?

- It is sometimes argued that health professionals should not share their own experiences as a patient, yet in this example it proved helpful. Does this make you reflect on this issue differently?

- Having read this article is there anything you have read or reflected on that might alter your practice? 